\title{
Porcine liver: experimental model for the intra-hepatic glissonian approach ${ }^{1}$
}

\author{
Figado suíno: modelo experimental para o acesso glissoniano intra-hepático
}

\author{
Antonio Cavalcanti de Albuquerque Martins ${ }^{\mathrm{I}}$, Marcel Autran Cesar Machado II, Álvaro Antonio Bandeira Ferraz ${ }^{\mathrm{III}}$ \\ ${ }^{\text {I }}$ Master, Fellow PhD degree, Department of Surgery, Federal University of Pernambuco (UFPE), Assistant Professor, Pernambuco \\ School of Medicine - FBV/IMIP, Brazil, General Surgery Service, IMIP, Brazil. \\ II PhD, Associate Professor Transplant and Liver Surgery Unit, Clínics Hospital, Shool of Medicine, University of São Paulo (USP), \\ Brazil. \\ ${ }^{\text {III }} \mathrm{PhD}$, Associate Professor Department of Surgery, UFPE, Brazil.
}

\begin{abstract}
Purpose: The aim of the study is to evaluate the porcine liver as a teaching and training model for the glissonian approach. Methods: Ten livers were removed from domestic adult white pigs weighting 35 to $45 \mathrm{~kg}$. Based on anatomical landmarks, the glissonian pedicles of each liver segments were dissected and biopsies were taken for histological examination, to analyze the presence of the glissonian sheath. Results: During microscopic examination, a sheath of conjunctive tissue was observed wrapping each segmental pedicle in porcine liver. This could be clearly seen when histological preparation for connective tissue was obtained (Masson technique). Conclusion: The morphological arrangement of glissonian pedicles in porcine liver makes this model a useful tool for training the intra-hepatic glissonian approach.
\end{abstract}

Key words: Liver. Anatomy. Histology. Comparative Anatomy. Hepatectomy

\section{RESUMO}

Objetivo: Avaliar a utilização do fígado suíno como um modelo experimental para o ensino e treinamento da técnica glissoniana intra-hepática nas ressecções do fígado.

Métodos: Foram utilizados 10 fígados inteiros de porcos adultos brancos, pesando entre $35-45 \mathrm{~kg}$. Os pedículos glissonianos de vários segmentos foram dissecados e ressecados para a realização de estudos histológicos e verificação da presença da bainha conjuntiva ao longo das tríades portais. Resultados: Na microscopia, uma bainha de tecido conjuntivo foi encontrada envolvendo os pedículos glissonianos no fígado suíno. A utilização de preparações específicas para o tecido conjuntivo (Masson) ressaltou a presença dessa bainha em cada pedículo. Conclusão: As características morfológicas dos pedículos glissonianos suínos, fazem desse modelo experimental um método de treinamento da técnica glissoniana intra-hepática.

Descritores: Fígado. Anatomia e histologia. Anatomia comparada. Hepatectomia.

1. Research performed at Experimental Surgical Research Laboratory (NCE), UFPE, Brazil 


\section{Introduction}

Domestic pigs have been used in experimental surgery due to anatomical and physiological similarities with humans. The size of the porcine liver - comparable to the human organ - makes it an ideal model for training surgeons in liver surgery and transplantation. Moreover, this experimental model has been considered inexpensive, resistant and easily available ${ }^{1,2,3}$.

The intra-hepatic glissonian approach has been considered an advance in the modern hepatic surgery by allowing a safe resection, with minor bleeding and maximum preservation of hepatic tissue. This approach relies on the anatomical opportunity created by the presence of a sheath that envelops the portal triad (portal vein, hepatic artery and biliary duct $)^{4-8}$. Training for this complex technique has been limited to observing its clinical use in the few surgical departments that use this approach for hepatic resections $s^{4,5,6}$

The porcine liver has been shown to display an arrangement that resembles the segmental aspects described by Couinaud in the human liver ${ }^{2}$. However, the presence of glissonian pedicles for each hepatic segment, as seen in the human liver, has never been mentioned or demonstrated in the literature.

\section{Objective}

Evaluate the porcine liver as a teaching and training model for performing intra-hepatic glissonian resections.

\section{Anatomical Considerations}

Swine liver has three main lobes: right lateral, median and left lateral. These lobes are divided by deep interlobar fissures. The median lobe can be subdivided, by the umbilical fissure, in two paramedian lobes, named left and right median lobes. Unlike humans, the left lateral lobe is the biggest lobe in pigs. The caudate lobe is normally attached to the right lateral lobe by a ligament that runs in a small fissure. The inferior vena cava is intraparenchymal and runs within the caudate lobe. The gallbladder is located in the right median lobe with a small impression on the adjacent left median lobe. The cystic duct is long and runs for a long extension on the visceral surface of the liver, where it joins a short hepatic duct ${ }^{2,3}$ (Figure 1.1).

Owing to the prominent fissures in swine liver, it is very easy to identify the right and left hemi-livers. Like humans, there are no branches of bile ducts, hepatic artery and portal vein that cross the left and right hemi-livers in the majority of cases ${ }^{2}$.

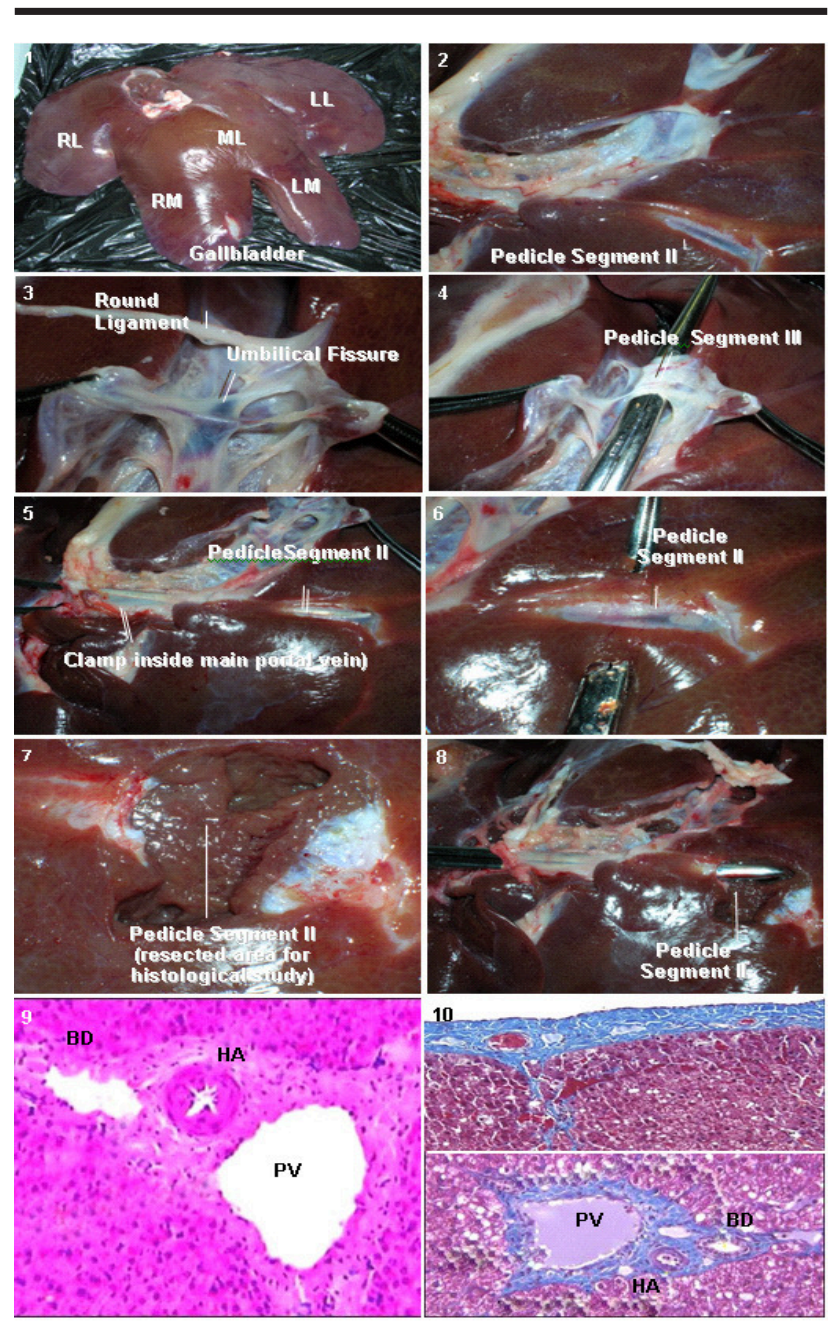

FIGURE 1 - 1. Overview. Diaphragmatic surface of porcine liver and its main lobes right lateral (RL), median (M) and left lateral (LL). The median lobe has two paramedian lobes, named left (LM) and right median (RM) lobes. 2. Visceral surface. The umbilical fissure and the superficially located pedicle of the segment II. 3. Umbilical fissure. The pedicles of segments II, III and IV and round ligament are seen. 4. Isolated pedicle of segment III. 5. Visceral surface of left lobe. A Kelly clamp has been inserted into the portal vein comprised into the pedicle of segment II. 6. Isolation of the pedicle of segment II by using small hepatic incisions. 7 and 8 . Hepatic tissue, including the pedicle, has been resected for histological analysis. 9. Hematoxilin-eosin preparation of the resected segment. 10. Masson histological preparation. Upper image: the conjunctive tissue at the liver capsule is readily demonstrated in a bluish color. Lower image: Conjunctive tissue is also seen around the portal triad. PV: Portal Vein, HA: hepatic artery and BD: bile duct. 
The porcine liver can be divided in eight segments, comparable to those described in the human liver by Claude Couinaud. Each segment has its own arterial/venous supply and biliary drainage. The left lateral lobe is divided in segment II and III, and the right lateral lobe into segments VI, VII and I. The left median lobe is the segment IV, and the right median can be divided in segments V and VIII ${ }^{2}$ (Figure 1.1). In this fashion, the left lateral e left medial lobes corresponds to human left liver and the right lateral and right medial to the right human liver.

The interlobular zones are characterized by considerable connective tissue within which vascular and biliary pedicles are found ${ }^{1}$.

\section{Methods}

\section{Livers and Dissection}

Ten livers were removed from adult, domestic, white pigs (Landrace) in a private slaughterhouse lawfully established and supervised. The pigs weighed between 35 to $45 \mathrm{Kg}$.

Based on the segmental anatomy of the porcine liver, the pedicles for each segment were isolated using small incisions on the visceral surface of the liver, dissected and resected.

Biopsies were taken for histological examination (hematoxilin - eosin and Masson), to analyze the presence of a conjunctive (glissonian) sheath.

\section{Photographic documentation}

All steps were photographed using 4.0 Mega pixels digital camera (Nikon Coolpix 4600) adapted to a tripod (Hakuba, Japan).

\section{Results}

During inspection of the visceral surface, some pedicles were readily visible without any dissection along the fissures in the porcine liver (Figures 1.2, 1.3 and 1.4). The segment I have a well-defined pedicle within the fissure that separates this segment from the right lateral lobe. All pedicles were followed, starting at the main portal vein to confirm the segmentation pattern (Figure 1.5). It was clear, from these dissections, the presence of branches of the portal vein, hepatic artery and bile duct on each pedicle (Figures.1.4 and 1.6). Some pedicles (II/III, V and I) were often observed in a superficial course in the visceral surface of pig liver. The pedicles were traced, dissected, isolated and biopsies were taken for histological studies (Figures 1.2 to 1.8 ). The umbilical fissure is a meeting point where some pedicles can be easily isolated as happens in the human liver (Figure 1.3). The resection was accomplished with an extension of the surrounding liver parenchyma, to confirm the complete extension of the sheath enveloping the glissonian pedicles (Figures 1.6, 1.7 and 1.8). The histological sections demonstrated portal trinities enveloped with conjunctive tissue, very similar to the ones present in the human liver (Figures 1.9 and 1.10).

\section{Discussion}

The learning curve for a surgical technique requires anatomical knowledge and theoretical information about the steps required to accomplish the procedure. Once these basic requirements are completed, the surgeon must acquire precision and perfect his/her surgical skills. However, to fulfill the basic requirements to master a surgical technique, several consecutive steps, including theory and practical training, must be followed. The duration of this process is directly dependent on the exposition of the surgeon to the specific technique. Normally, this process starts with literature review, followed by anatomical dissections and surgical training in animals and cadavers. Video sessions and workshops are very important in the transition to start experiencing the application of the technique on the real setting, which can be fulfilled by observing and helping real surgery in experienced departments ${ }^{9}$.

In complex surgical techniques, as the intra-hepatic glissonian approach, there is a gap between the theory and clinical application. The lack of experimental models and laboratory dissection of liver are particularly troublesome factors in this learning curve, as training in this complex technique has been limited to observing its clinical use in the few surgical departments where it is used routinely 9 .

Anatomical dissections in human livers seem to be a very important step to safely perform a glissonian approach during real liver surgery. On the other hand, the difficulties in obtaining anatomical human specimens to teach surgeons have called for suitable alternatives ${ }^{9}$. In this context, clarifying specific aspects of the porcine liver anatomy that prove it a suitable model to learn and practice the intra-hepatic glissonian approach are useful. If proved suitable, the porcine model can fill the experimental gap in the learning curve by surgical dissections of the porcine isolated livers or, later on, during experimental surgery under general anesthesia.

Apart from the some anatomical differences between human and porcine liver, and the need to have a good comparative anatomical knowledge between these species, the presence of glissonian pedicles in pig livers and the possibility to isolate them during experimental surgery, makes the porcine liver a good and reliable model to perform segmentectomies and hepatectomies using an intra-hepatic glissonian approach.

\section{Conclusion}

The anatomical and histological arrangement of glissonian pedicles in porcine liver make this experimental model a useful tool for learning and training the intra-hepatic glissonian approach in liver resections.

\section{References}

1. Camprodon R, Solsona J, Guerrero JA, Mendonza CG, Segura J, Fabregat JM. Intra-hepatic vascular division in the pig - Basis for partial hepatectomies. Arch Surg. 1977; 112:38-40. 
2. Court FG, Wemyss-Holden AS, Morrison CP, Teague BD, Laws PE, Kew J, Dennison AR, Maddern GJ. Segmental nature of the porcine liver and potential as a model for experimental partial hepatectomy. Br J Surg. 2003; 90:440-4.

3. Zanchet DJ, Montero EFS. Pig Liver Sectorization and Segmentation and Virtual Reality Depiction. Acta Cir bras 2002; 17:381-7.

4. Jamieson GG, Launois B. The posterior intrahepatic approach for hepatectomy or removal of segments of the liver. Surg Gynecol Obstet. 1992; 174: $15-8$.

5. Launois B, Jamieson GG. The importance of Glisson's capsule and its sheaths in the intrahepatic approach to resection of the liver. Surg Gynecol Obstet. 1992; 174: 7-10.

6. Blumgart LH, Janargan W, Fong Y. Liver resection for benign disease and for liver and biliary tumours. In: Blumgart LH, Fong Y. Surgery of the liver and biliary tract. $3^{\text {a }}$ ed. New York: W. B. Saunders; 2003. p 1639-714.

7. Machado MA, Herman P, Machado MC. Intrahepatic Glissonian approach for pedicle control during anatomic mesohepatectomy. Surgery. 2007;141(4):533-7.

8. Machado MA, Herman P, Figueira ER, Bacchella T, Machado MC. Intrahepatic Glissonian access for segmental liver resection in cirrhotic patients. Am J Surg. 2006; 192(3):388-92.

9. Martins ACA. Fígado Isolado de Cadáver e Imagens Tridimensionais - Modelo Experimental Para Treinamento do Acesso Glissoniano IntraHepático nas Ressecções Hepáticas. [Mestrado].Universidade Federal de Pernambuco - Centro de Ciências da Saúde; 2004. 97p.

\section{Correspondece:}

Antonio Cavalcanti de Albuquerque Martins Rua Deputado Pedro Pires Ferreira, 325/ 1601 52050-480 Recife-PE, Brasil

Phone: (81) 9973-8223/(81) 3267-2670 acam@elogica.com.br
Conflict of interest: None Financial Source: None

Received: October 30, 2007 Review: November 28, 2007 Accepted: January 14, 2008

\section{How to cite this article}

Martins ACA, Machado MAC, Ferraz AAB. Porcine liver: experimental model for the intra-hepatic glissonian approach. Acta Cir Bras. [serial on the Internet] 2008 Mar-Apr;23(2). Available from URL:http://www.scielo.br/acb 